\title{
Use of dry citrus pulp or soybean hulls as a replacement for corn grain in energy and nitrogen partitioning, methane emissions, and milk performance in lactating Murciano-Granadina goats
}

\author{
M. C. López, F. Estellés, V. J. Moya, and C. Fernández ${ }^{1}$ \\ Institute for Animal Science and Technology, Polytechnic University of Valencia, 46022 Valencia, Spain
}

\begin{abstract}
The aim of this study was to assess the effect of substitution of dietary corn grain by dry citrus pulp or soybean hulls on energy and nitrogen partitioning, substrate oxidation, methane emission, and milk performance in dairy goats during midlactation. Twelve multiparous Murciano-Granadina goats of similar body weight $(41.7 \pm 2.8 \mathrm{~kg})$ were split in 3 groups in an incomplete crossover design. One group of 4 goats was fed a mixed ration with $605 \mathrm{~g} / \mathrm{kg}$ of dry matter of corn grain (CRG), another group replaced corn grain with dry citrus pulp (CTP), and the last with soybean hulls $(\mathrm{SYH})$. The goats were allocated to individual metabolism cages. After $14 \mathrm{~d}$ of adaptation, feed intake, total fecal and urine output, and milk yield were recorded daily over a 5 -d period. Then, gas exchange measurements were recorded by a mobile open-circuit indirect calorimetry system using a head box. Dry matter intake was similar for all 3 groups $(1.53 \mathrm{~kg} / \mathrm{d}$, on average). Total replacement of the concentrate with fibrous by-products increased fiber apparent digestibility. The metabolizable energy intake was significantly greater for diet CRG than SYH (1,193 vs. $1,079 \mathrm{~kJ} / \mathrm{kg}$ of $\mathrm{BW}^{0.75}$, respectively), CTP showed an intermediate value. The heat production was higher for the fiber diet than starchy diet $\left(908\right.$ vs. $843 \mathrm{~kJ} / \mathrm{kg}$ of $\mathrm{BW}^{0.75}$ for SYH and CRG, respectively). The efficiency of use of metabolizable energy for milk production obtained by regression was 0.59 . Goats fed CTP and SYH diets produced similar $\mathrm{CH}_{4}$ emissions (34.8 $\mathrm{g} / \mathrm{d}$, on average), significantly higher compared with goats fed the CRG $\operatorname{diet}(24.7 \mathrm{~g} / \mathrm{d})$. Goats of the 3 treatments were in negative energy balance, so the oxidation of fat was greater than for carbohydrates. No significant differences were observed for milk production $(1.72 \mathrm{~kg} / \mathrm{d})$, and milk fat was significantly greater for a more fibrous diet compared with a starchy diet (6.57 vs. $4.95 \%$ in SYH and CRG, respectively).
\end{abstract}

Received May 30, 2014

Accepted September 12, 2014.

${ }^{1}$ Corresponding author: cjfernandez@dca.upv.es
Key words: lactating goat, cereal replacement, byproduct, energy partitioning, methane emission

\section{INTRODUCTION}

In Mediterranean countries, ruminant production is limited by the poor quality and scarcity of pastures, especially during periods of drought. Consequently, farmers are forced to use cereal-based concentrates and the demand of cereals for animal feeding increases the price of concentrate. This justifies the need to develop feeding strategies based on cost-effective alternatives and local feed resources, which would increase the sustainability of livestock-production systems and improves farmers' income. Agricultural by-products may be of interest not only to reduce feed cost, but also to reduce environmental problems associated with by-product accumulation (Vasta et al., 2008).

Increasing interest in by-products has occurred as partial substitution of traditional feedstuffs in ruminant feeding has become more prevalent. From a nutritional point of view, by-products are included in the ration to supply energy and protein, but are often also characterized by high fiber content. This is the case with citrus pulp or soybean hulls, which are typically used as grain replacers. A large number of the citrus by-products feedstuffs, including citrus pulp, are suitable for inclusion in ruminant diets because of the ability of ruminants to ferment high-fiber feeds in the rumen (Grasser et al., 1995). According to FEDNA (2010), the NDF level of dry citrus pulp is intermediate (25\%), between that of most concentrates and forages, and contains relatively large amounts of pectins (25\%) and sugars (23\%), a small amount of ADL (2\%), and a very limited amount of available nitrogen ( $6 \%$ of $\mathrm{CP}$ ). Soybean hulls are high in NDF (58\%, high in cellulose) but low in ADL (2\%) and NFC (24\%).

Dietary composition affects the ruminal fermentation and, consequently, energy metabolism, $\mathrm{CH}_{4}$ emissions, and milk composition. Methane is an undesirable end product of rumen fermentation as it represents an energy loss to the animal and because it is a major 
greenhouse gas. In ruminant nutrition, decreased production of $\mathrm{CH}_{4}$ can represent an improvement in feed efficiency, because ruminants loose between 2 and $12 \%$ of the gross dietary energy in the form of $\mathrm{CH}_{4}$ (Johnson and Johnson, 1995). Besides, ruminants contribute to global warming through $\mathrm{N}$ excretion from urine and feces. To reduce $\mathrm{N}$ excretion and improve $\mathrm{N}$ efficiency of ruminant, dietary levels of $\mathrm{N}$ and optimal balance between $\mathrm{N}$ and energy substrates in the diet should be targeted.

Our hypothesis was that citrus pulp and soybean hulls could replace cereal-based concentrate in goat diets without compromising energy and protein partitioning in lactating goats when mixed diets were formulated with similar amounts of energy and protein. The purpose of the present experiment was to study the effect of substitution of corn grain in the mixed diet by dry citrus pulp or soybean hulls on energy partitioning, $\mathrm{CH}_{4}$ emissions, $\mathrm{C}$ and $\mathrm{N}$ balance, and milk performance in dairy goats during midlactation.

\section{MATERIALS AND METHODS}

\section{Animals and Feeding}

The experimental procedure was approved by the Animal Use and Care Committee of the Polytechnic University of Valencia (Spain) and followed the codes of practice for animals used in experimental works proposed by the European Union (2003). Twelve multiparous mature and nonpregnant Murciano-Granadina goats of similar BW $(41.7 \pm 2.8 \mathrm{~kg})$ and in midlactation were randomly split into 3 groups (4 goats per treatment) in an incomplete crossover design. Treatments consisted of 3 different concentrate mixed rations (Table 1). Goats were fed daily $0.25 \mathrm{~kg}$ of cereal straw as forage and $1.5 \mathrm{~kg}$ of concentrate (forage:concentrate ratio $=14: 86)$. The concentrate was mixed and pelleted along with the premix. One group was fed concentrate with $605 \mathrm{~g} / \mathrm{kg}$ of DM of corn grain (CRG). The other 2 groups substituted corn grain with by-products: dry citrus pulp (CTP) and soybean hulls (SYH). Chemical composition shown in Table 1 is the whole mixed ration (forage and pelleted concentrate). The mean gross energy $(\mathbf{G E})$ of the 3 diets was $17.6 \mathrm{MJ} / \mathrm{kg}$ of DM. The main difference among diets was the source of carbohydrates. Starch levels were 41.6, 6.4, and 1.5\% (on a DM basis) for the CRG, CTP, and SYH diets, respectively. Neutral detergent fiber and neutral detergent soluble fiber (NDSF) values were 30.1 and $8.5 \%$ (respectively, DM basis) for CRG, 30.1 and $24.1 \%$ (respectively, DM basis) for CTP, and 59.0 and $17.1 \%$ (respectively, DM basis) for SYH. Mixed diets contained similar amounts of CP (15.8\%, DM basis). Nutrient requirements followed the recommendation of Lachica and Aguilera (2003) and Calsamiglia et al. (2009) for goats in lactation. Apparent total tract digestibility, gas exchange, energy partitioning, $\mathrm{C}$ and $\mathrm{N}$ balance, oxidation of nutrients, and milk composition and yield were determined. Moreover, ruminal fermentation parameters were determined in the second period of the experiment. Half the daily ration was offered at 0800 $\mathrm{h}$ and half at $1600 \mathrm{~h}$. Goats had free access to water.

\section{Experimental Schedule and Measurements}

The experiment was conducted in an incomplete crossover design in two 31-d periods. During the adaptation, goats were fed experimental diets in pens for $7 \mathrm{~d}$ and then allocated in individual metabolism cages at thermoneutrality $\left(20-23^{\circ} \mathrm{C}\right.$ determined by a Hobo probe, Onset Data Loggers, Cape Cod, MA) for another $7 \mathrm{~d}$. Next, data on the feed offered and refused

Table 1. Ingredients and chemical composition of the diets

\begin{tabular}{|c|c|c|c|}
\hline \multirow[b]{2}{*}{ Item } & \multicolumn{3}{|c|}{$\operatorname{Diet}^{1}$} \\
\hline & CRG & CTP & SYH \\
\hline \multicolumn{4}{|l|}{ Ingredient, g/kg of DM } \\
\hline Barley straw (as a forage) & 150.0 & 150.0 & 150.0 \\
\hline Corn & 605.2 & — & - \\
\hline Soy hulls & - & — & 610.0 \\
\hline Citrus pulp & - & 605.2 & - \\
\hline Soy meal $(44 \% \mathrm{CP})$ & 202.4 & 221.7 & 173.9 \\
\hline Calcium carbonate & 21.6 & 4.0 & 22.9 \\
\hline Salt & 10.8 & 9.1 & 25.5 \\
\hline Bypass fat ${ }^{2}$ & 5.0 & 5.0 & 12.7 \\
\hline Premix $^{3}$ & 5.0 & 5.0 & 5.0 \\
\hline \multicolumn{4}{|l|}{$\begin{array}{l}\text { Chemical composition, \% of DM } \\
\text { (unless otherwise noted) }\end{array}$} \\
\hline $\mathrm{DM}, \%$ & 88.36 & 88.41 & 90.15 \\
\hline $\mathrm{OM}$ & 92.80 & 91.96 & 89.28 \\
\hline $\mathrm{CP}$ & 16.66 & 15.80 & 14.79 \\
\hline Ether extract & 2.66 & 2.10 & 2.03 \\
\hline $\mathrm{NDF}$ & 30.11 & 30.08 & 58.97 \\
\hline $\mathrm{ADF}$ & 8.55 & 16.69 & 37.55 \\
\hline Lignin & 0.44 & 0.93 & 1.22 \\
\hline $\mathrm{NDSF}^{4}$ & 8.51 & 24.09 & 17.07 \\
\hline $\mathrm{NFC}^{5}$ & 45.30 & 43.98 & 13.50 \\
\hline Starch & 41.63 & 6.36 & 1.45 \\
\hline Sugar + pectin $^{6}$ & 1.75 & 37.63 & 12.05 \\
\hline Gross energy, MJ/kg of DM & 18.00 & 17.56 & 17.21 \\
\hline
\end{tabular}

${ }^{1} \mathrm{CRG}=$ corn grain diet; $\mathrm{CTP}=$ citrus pulp diet; $\mathrm{SYH}=$ soy hulls diet. ${ }^{2}$ Bypass fat of palm FA distillate. Provided by Norel Animal Nutrition (Norel S.A., Madrid, Spain).

${ }^{3}$ Provided by Nacoop S.A. (Madrid, Spain). Premix composition: 40 $\mathrm{mg}$ of Se/kg, $250 \mathrm{mg}$ of $\mathrm{I} / \mathrm{kg}, 80 \mathrm{mg}$ of $\mathrm{Co} / \mathrm{kg}, 3,000 \mathrm{mg}$ of $\mathrm{Cu} /$ $\mathrm{kg}, 6,000 \mathrm{mg}$ of $\mathrm{Fe} / \mathrm{kg}, 23,400 \mathrm{mg}$ of $\mathrm{Zn} / \mathrm{kg}, 29,000 \mathrm{mg}$ of $\mathrm{Mn} / \mathrm{kg}$, $60,000 \mathrm{mg}$ of $\mathrm{S} / \mathrm{kg}, 60,000 \mathrm{mg}$ of $\mathrm{Mg} / \mathrm{kg}, 2,000,000 \mathrm{IU}$ of vitamin A/ $\mathrm{kg}, 400,000 \mathrm{IU}$ of vitamin $\mathrm{D}_{3} / \mathrm{kg}, 2,000 \mathrm{mg}$ of vitamin $\mathrm{E} / \mathrm{kg}, 10,000 \mathrm{mg}$ of nicotinic acid $/ \mathrm{kg}$, and 20,300 $\mathrm{mg}$ of choline $/ \mathrm{kg}$.

${ }^{4} \mathrm{NDSF}=$ neutral detergent-soluble fiber.

${ }^{5} \mathrm{NFC}=100-(\mathrm{NDF}+$ ash $+\mathrm{CP}+$ ether extract $)$.

${ }^{6}$ Sugars + pectins $=$ NFC - starch. 
and the total fecal, urine, and milk output were recorded daily for each goat during a 5-d period, as well as BW at the beginning and end of the period. Feces were collected in wire-screen baskets placed under the floor of the metabolism crates and urine was collected through a funnel into plastic buckets containing an adequate amount of a solution of $\mathrm{H}_{2} \mathrm{SO}_{4} 10 \%$ ( $\mathrm{vol} / \mathrm{vol}$ ) to acidify the urine of each goat. The acidification of urine was necessary to prevent microbial degradation and the loss of volatile ammonia-N $\left(\mathrm{NH}_{3}-\mathrm{N}\right)$. Representative samples $(10 \%)$ of diet, feces, and urine were collected over 5 consecutive days, stored at $-20^{\circ} \mathrm{C}$, and pooled for chemical analysis. The goats were milked once daily at $0800 \mathrm{~h}$ with a portable milking machine (Flaco, model DL-170, J. Delgado S.A., Ciudad Real, Spain). Immediately after milking, the individual milk yield was measured and a sample of $10 \%$ was put in a bottle and frozen until analysis. In addition, samples were collected into a plastic vial that contained $20 \mathrm{mg}$ of potassium dichromate as a preservative and taken to the Interprofessional Dairy Laboratory of the Valencia Community Region (Valencia, Spain) for compositional analysis. Ruminal fluid samples were collected by stomach tube before the morning feeding on the last day of apparent digestibility trial. Ruminal fluid $\mathrm{pH}$ was immediately determined using a model $265 \mathrm{~A}$ portable $\mathrm{pH}$ meter (Orion Research Inc., Beverly, MA). A ruminal fluid sample was acidified with $\mathrm{H}_{2} \mathrm{SO}_{4}$ and frozen until later determination of $\mathrm{NH}_{3}-\mathrm{N}$. Samples for analysis of VFA were mixed with $\mathrm{H}_{3} \mathrm{PO}_{4}$ and kept frozen until analysis.

Next, gas exchange was measured for each goat during $24 \mathrm{~h}$ (4 goats/treatment) by an indirect calorimetric system based on a ventilated head-box designed for small ruminants. To this end, $12 \mathrm{~d}$ were taken for each period in the incomplete cross over design. The respirometry system has a head hood, a flow meter (Thermal Mass Flowmeter Sensyflow VT-S, ABB, Alzenau, Germany), and air suction provided by a centrifugal fan (CST60 Soler Palau Inc., Parets del Vallès, Barcelona, Spain). The $\mathrm{CH}_{4}$ and $\mathrm{CO}_{2}$ concentrations were measured using the infrared principle and $\mathrm{O}_{2}$ was measured by the paramagnetic principle (Easyflow Gas Analyzer, model 3020, ABB). Although the unit was an autocalibrated model, the analyzers were calibrated with reference gases before each test. Fernández et al. (2012) described the mobile open-circuit respirometry system used for these measurements.

The whole system was calibrated injecting pure $\mathrm{N}_{2}$ and $\mathrm{CO}_{2}$ into the head box (McLean and Tobin, 1987) determined gravimetrically using a precision scale. Calibration factors were calculated according to Brockway et al. (1971). The $\mathrm{CH}_{4}$ and $\mathrm{CO}_{2}$ production and $\mathrm{O}_{2}$ consumption were calculated as described by Aguilera and Prieto (1986). An initial atmospheric air sample was collected and the gas concentrations were used as reference for calculations.

\section{Chemical Analysis}

Feed, feed refusals, and feces samples were first dried in a forced-air oven at $55^{\circ} \mathrm{C}$ for $48 \mathrm{~h}$ then ground to pass a 1-mm screen before analysis. Urine and milk was dried by lyophilization. Chemical analyses of the diet, refusals, and feces were conducted according to methods of AOAC International (2000) for DM, ash, and ether extract. Dry matter of diets and feces was determined by oven-drying at $102 \pm 2^{\circ} \mathrm{C}$ for $24 \mathrm{~h}$. Ash concentration was measured by incineration in an electric muffle furnace at $550^{\circ} \mathrm{C}$ for $6 \mathrm{~h}$ to determine OM. Ether extract was extracted with petroleum ether after acid hydrolysis to recover saponified fat (Soxtec System HT Tecator, Hillerød, Denmark; 1047 Hydrolyzing Unit and 1043 Extraction Unit). The NDF and ADF were measured in an Ankom Fiber Analyzer (A220, Ankom Technologies, Fairport, NY) according to Mertens (2002) and AOAC International (2000), respectively. The NDF was determined using sodium sulfite and $\alpha$-amylase. Lignin was determined according to Robertson and Van Soest (1981). The NDSF content was determined according to Hall et al. (1997) after adapting the method to the modifications proposed by Martínez-Vallespín et al. (2011). The NFC content of diets was calculated by the difference method based on chemical analysis of individual feeds (NRC, 2001) as $\mathrm{NFC}=100-\mathrm{NDF}-$ ash $-\mathrm{CP}-$ ether extract. Gross energy content of the dried samples (feed, feces, urine, and milk) was analyzed by combustion in an adiabatic bomb calorimeter (Gallenkamp Autobomb; Loughborough, UK). Starch content was determined by enzymatic method ( $\alpha$-amylase obtained from Sigma-Aldrich, Steinheim, Germany) according to Batey (1982). The C and N were analyzed by the Dumas principle (TruSpec CN; Leco Corporation, St. Joseph, $\mathrm{MI}$ ). Multiplying $\mathrm{N}$ by a factor of 6.25 converted the results to CP. Milk composition (fat, protein, lactose, and total milk solids content) was analyzed with infrared analyzer (MilkoScan FT120 Foss Electric, Hillerød, Denmark).

The $\mathrm{NH}_{3}-\mathrm{N}$ content of ruminal fluid samples was analyzed by the Kjeldahl procedure (2300 Kjeltec Analyzer Unit, Foss Tecator). Determination of ruminal VFA was based on the method described by Jouany (1982) using a gas chromatograph (Fisons 8000 series; Fisons Instruments SpA, Milan, Italy) equipped with a split/ splitless injector and flame ionization detector. 


\section{Calculations}

The ME intake (MEI) was calculated as the difference between GE intake and energy losses in feces, urine, and $\mathrm{CH}_{4}$ (with an energy equivalent value of 39.5 $\mathrm{kJ} / \mathrm{L} \mathrm{CH}_{4}$; Brouwer, 1965). The heat production (HP) was determined from measurements of $\mathrm{O}_{2}$ consumption, $\mathrm{CO}_{2}$ and $\mathrm{CH}_{4}$ production, and urine $\mathrm{N}\left(\mathbf{N}_{\text {urine }}\right)$, using the equation of Brouwer (1965):

$$
\begin{gathered}
\mathrm{HP}(\mathrm{kJ})=16.18 \times \mathrm{O}_{2}+5.02 \times \mathrm{CO}_{2} \\
-2.17 \times \mathrm{CH}_{4}-5.99 \times \mathrm{N}_{\text {urine }},
\end{gathered}
$$

where gases were expressed in liters per day and $\mathrm{N}_{\text {urine }}$ in grams per day. The body tissue energy $\left(\mathbf{R E}_{\text {body }}\right)$ was calculated as MEI - HP - milk energy $\left(\mathbf{E}_{\text {milk }}\right)$.

The energy associated with the oxidation of protein (OXP), carbohydrate (OXCHO), and fat (OXF) was calculated by the method of Brouwer (1958) and Chwalibog et al. (1997) for ruminants. The $\mathrm{CO}_{2}$ production from oxidation $\left(\mathbf{C O}_{2 \mathrm{x}}\right)$ was calculated as $\mathrm{CO}_{2}$ - $\left(1.7 \times \mathrm{CH}_{4}\right)$, according to Fahey and Berger (1988). The calculations were carried as follows:

$$
\begin{gathered}
\text { OXP }=6.25 \times \mathrm{N}_{\text {urine }} \times 18.42(\mathrm{~kJ} / \mathrm{g}), \\
\mathrm{OXCHO}=\left(-2.968 \times \mathrm{O}_{2}+4.174 \times \mathrm{CO}_{2 \mathrm{x}}\right. \\
\left.-2.446 \times \mathrm{N}_{\text {urine }}\right) \times 17.58(\mathrm{~kJ} / \mathrm{g}), \\
\mathrm{OXF}=\left(1.719 \times \mathrm{O}_{2}-1.719 \times \mathrm{CO}_{2 \mathrm{x}}\right. \\
\left.-1.963 \times \mathrm{N}_{\text {urine }}\right) \times 39.76(\mathrm{~kJ} / \mathrm{g}) .
\end{gathered}
$$

Then, the HP from oxidation $(\mathbf{H P x})$ was:

$$
\begin{gathered}
\mathrm{HPx}(\mathrm{kJ})=16.18 \times \mathrm{O}_{2}+5.02 \\
\times \mathrm{CO}_{2 \mathrm{x}}-5.99 \times \mathrm{N}_{\text {urine }} .
\end{gathered}
$$

Again, gases were expressed in liters per day and $\mathrm{N}_{\text {urine }}$ in grams per day. Heat of fermentation (HPf) was estimated subtracting HP from HPx. The nonprotein respiratory quotient from oxidation of nutrients (RQnpx) was determined as RQnpx $=\left[\mathrm{CO}_{2 \mathrm{x}}-\left(\mathrm{N}_{\text {urine }} \times 6.25\right.\right.$ $\times 0.774)] /\left[\mathrm{O}_{2}-\left(\mathrm{N}_{\text {urine }} \times 6.25 \times 0.957\right)\right]$. For $\mathrm{C}$ and $\mathrm{N}$ balance, we followed the equation and values proposed by McLean and Tobin (1987), and the grams retained in protein $\left(\mathbf{R}_{\text {protein }}\right)$ and fat $\left(\mathbf{R}_{\mathrm{fat}}\right)$ were calculated.

The efficiency of use of ME for lactation $\left(\mathbf{k}_{1}\right)$ was calculated according to AFRC (1993). If the goat is in positive tissue energy balance, some of the MEI is being directed toward tissue energy retention and therefore
MEI is corrected [AFRC, 1993; value for efficiency of utilizing MEI for gain $\left(\mathrm{k}_{\mathrm{g}}\right)$ is 0.6$]$. When the goat is in negative energy balance, some of the $\mathrm{E}_{\text {milk }}$ is derived from body stores and therefore $\mathrm{E}_{\text {milk }}$ is corrected [efficiency of utilizing body stores for milk production $\left(\mathrm{k}_{\mathrm{t}}\right)$ is 0.84 according to AFRC, 1993]. Therefore, corrected $\mathrm{E}_{\text {milk }}$ was regressed on corrected MEI using a linear regression: $\mathrm{k}_{1}$ was the slope of the line and the ME for maintenance $\left(\mathbf{M E}_{\mathbf{m}}\right)$ denotes the value of MEI when $\mathrm{E}_{\text {milk }}$ is zero. Net energy for lactation was computed as MEI $\times \mathrm{k}_{1}$.

\section{Statistical Analysis}

The effects of corn substitution with by-products on intake, digestibility, ruminal fermentation parameters, milk yield, energy and C-N balances, and oxidation of nutrients were analyzed using the PROC GLM of SAS (2001). The experiment was conducted as an incomplete crossover design and the model for the dependent variables included the fixed effect of diet and period and their interaction. The following statistical model was used: $\mathrm{Y}=\mu+\mathrm{D}+\mathrm{T}+(\mathrm{D} \times \mathrm{T})+\varepsilon$, where $\mathrm{Y}$ is the dependent variable; $\mu$ is the overall mean; $\mathrm{D}$ and $\mathrm{T}$ are the fixed effects of diet and period, respectively; D $\times \mathrm{T}$ is the fixed interaction effect of diet $\times$ period; and $\varepsilon$ is the random error. Effects were declared significant at $P<0.05$ and $P$-values between 0.05 and 0.10 were considered as a trend. Tukey tests were used for multiple comparisons among diets and Student's $t$-test was used for the period.

\section{RESULTS AND DISCUSSION}

\section{Feed Intake, Digestibility, and Rumen Fermentation}

Intake and apparent total-tract digestibility of nutrients by Murciano-Granadina dairy goats are shown in Table 2. Dry matter, NDF, and starch digestibility were significantly $(P<0.05)$ affected by the period, being higher during the second digestibility than the first. No effect of interaction (diet $\times$ period) was found, with the exception of starch. In relation to the effect of the diet, DMI was similar for the 3 diets $(1.54 \mathrm{~kg} / \mathrm{d}$, on average). Diet affected $(P<0.001)$ the apparent totaltract digestibility of most nutrients, as expected from a change in diet, which involves reducing starch and increasing fiber. The higher level of undigestible material for diet SYH compared with CRG and CTP (59\% NDF, DM basis for SYH, and 30\% NDF, DM basis for CRG and CTP, on average) appeared to be the main factor responsible for the decrease of DM, OM, NFC, and GE apparent digestibility in SYH. Consequently, goats fed high-concentrate diets are often associated 
Table 2. Body weight, intake, and apparent digestibility coefficients of Murciano-Granadina goats $(\mathrm{n}=12)$ during midlactation according to the type of diet

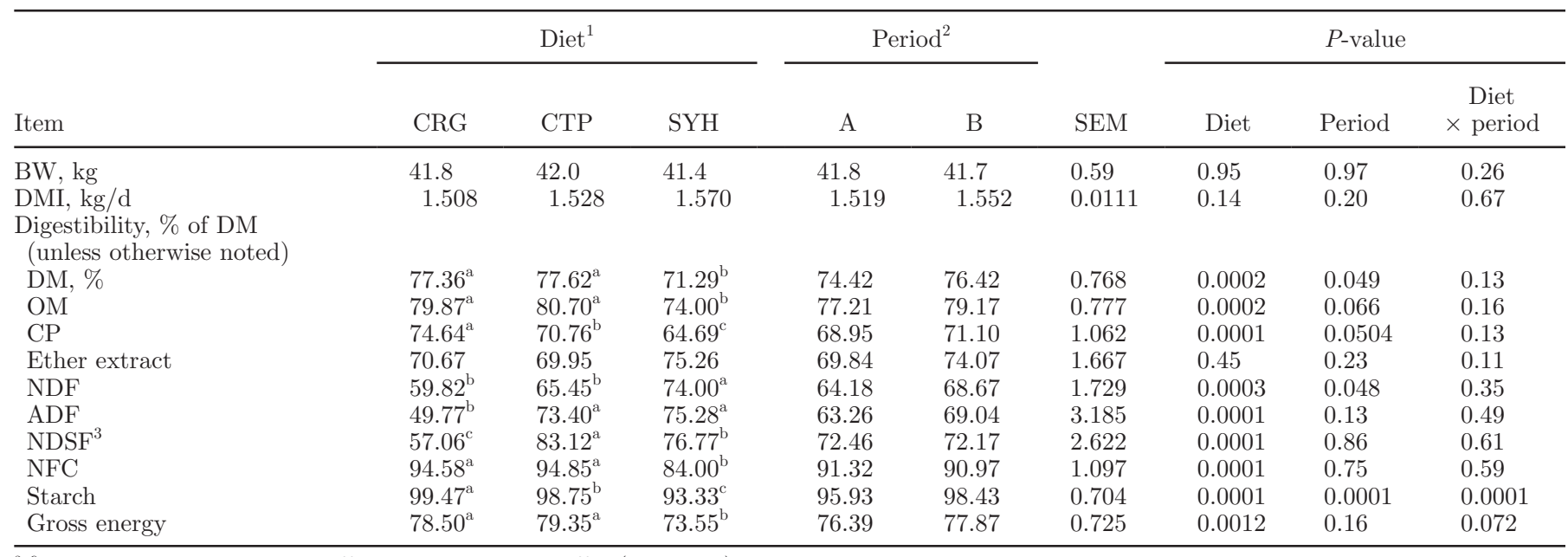

${ }^{\mathrm{a}-\mathrm{c}}$ Means within a row with different superscripts differ $(P<0.05)$.

${ }^{1} \mathrm{CRG}=$ corn grain diet; $\mathrm{CTP}=$ citrus pulp diet; $\mathrm{SYH}=$ soy hulls diet

${ }^{2} \mathrm{~A}=$ first period; $\mathrm{B}=$ second period.

${ }^{3} \mathrm{NDSF}=$ neutral detergent-soluble fiber.

with greater DM and OM and lower NDF digestibility (Kawas et al., 1991).

Rumen fermentation parameters obtained are shown in Table 3. It was not possible to assess the effect of period and interaction with diet because rumen liquid extraction was done only during the second period of the trial. The highest level of starch on diet CRG was the cause of the lower $\mathrm{pH}$ of CRG than CTP and $\mathrm{SYH}$ $\operatorname{diet}(6.9,7.4$, and 7.3 , respectively). Goats fed with more starch also had a greater and significant $(P<$ $0.05) \mathrm{NH}_{3}-\mathrm{N}$ concentration (24.59 mg/dL for CRG) than other diets (12.69 and $17.74 \mathrm{mg} / \mathrm{dL}$ for CTP and SYH, respectively). Ariza et al. (2001) also obtained higher $\mathrm{NH}_{3}-\mathrm{N}$ concentration via the starch diet than high-NDSF diet, 14.2 versus $9.3 \mathrm{mg} / \mathrm{dL}$ in hominy feed versus dry citrus pulp diets, respectively, in continuous culture. Differences were found in most of the VFA studied. Greater $(P<0.05)$ total VFA was found for diet SYH than CRG and CTP (33.15 $\mathrm{m} M$ for SYH vs. $22.74 \mathrm{~m} M$ for the average of CRG and CTP), suggesting more fermentation activity for diet SYH than others and accompanied by greater NDF and ADF digestibility. An increase $(P<0.05)$ in acetic acid in the rumen was observed when fiber amount of diets increased (62.9, 68.7, and $71.2 \mathrm{~mol} / 100 \mathrm{~mol}$ for CRG, CTP, and SYH, respectively). Conversely, the greater starch level of the CRG diet increased the production of propionic acid compared with the other diets $(15.3 \mathrm{~mol} / 100 \mathrm{~mol}$ for CRG vs. $13.4 \mathrm{~mol} / 100 \mathrm{~mol}$ for the average of CTP and $\mathrm{SYH})$ and butyric acid (15.1 mol/100 mol for CRG vs. $9.8 \mathrm{~mol} / 100 \mathrm{~mol}$ for the average of CTP and SYH), although the differences were not significant.

\section{Energy Balance}

The average value obtained for the calibration factor, by releasing a known volume of $\mathrm{N}_{2}$ or $\mathrm{CO}_{2}$ into the respirometry system, was $1.0056 \pm 0.00158$ and 0.9924 \pm 0.00915 for $\mathrm{O}_{2}$ and $\mathrm{CO}_{2}$, respectively. Daily energy balance obtained with the 3 diets is shown in Table 4 . A significant effect of period of time $(P<0.05)$ was observed in HP. The MEI, HP, and $\mathrm{RE}_{\text {body }}$ were significantly affected $(P<0.05)$ for the interaction diet and period. Regarding the effect of diet, no statistically significant differences were observed for GE intake $\left(1,649 \mathrm{~kJ} / \mathrm{kg}\right.$ of $\mathrm{BW}^{0.75}$, on average), but energy losses in feces were higher for SYH than CRG and CTP; in fact, GE digestibility of SYH was approximately $5.4 \%$ lower than other diets $(P<0.05)$. Therefore, we noted a reduction in digestible energy when feeding goats decreasing amounts of starch and soluble fiber. Urine energy losses were not different among treatments. Both CTP and SYH presented similar energy losses in $\mathrm{CH}_{4}\left(118 \mathrm{~kJ} / \mathrm{kg}\right.$ of $\mathrm{BW}^{0.75}$, on average) and were significantly higher $(P<0.001)$ than CRG $(84 \mathrm{~kJ} / \mathrm{kg}$ of $\mathrm{BW}^{0.75}$ ), indicating that increasing the level of starch in the diet reduces the $\mathrm{CH}_{4}$ production, as indicated by different authors and reviewed by Grainger and Beauchemin (2011). However, Romero-Huelva et al. (2012) found a reduction in $\mathrm{CH}_{4}$ production (from 110 to $67 \mathrm{~kJ} / \mathrm{kg}$ of $\mathrm{BW}^{0.75}$ ) when $35 \%$ of a cereal-based concentrate was replaced with feed blocks containing wastes of tomato and cucumber. Those authors concluded that the feed blocks might also have the presence of secondary plant compounds, which could act as 
Table 3. $\mathrm{pH}$, ammonia- $\mathrm{N}\left(\mathrm{NH}_{3}-\mathrm{N}\right)$, and VFA of Murciano-Granadina goats $(\mathrm{n}=12)$ during midlactation according to the type of diet

\begin{tabular}{lccccc}
\hline & \multicolumn{3}{c}{ Diet $^{1}$} & & \multicolumn{2}{c}{ P-value } \\
\cline { 2 - 4 } & CRG & CTP & SYH & SEM & Diet \\
\hline Item & 6.88 & 7.44 & 7.33 & 0.171 & 0.061 \\
$\mathrm{pH}$ & $24.59^{\mathrm{a}}$ & $12.69^{\mathrm{b}}$ & $17.74^{\mathrm{b}}$ & 3.447 & 0.048 \\
Total VFA, mM & $25.31^{\mathrm{b}}$ & $20.17^{\mathrm{b}}$ & $33.15^{\mathrm{a}}$ & 3.773 & 0.029 \\
Individual VFA, mol/100 mol & & & & & \\
Acetic acid & $62.94^{\mathrm{b}}$ & $68.69^{\mathrm{a}}$ & $71.19^{\mathrm{a}}$ & 2.441 & 0.035 \\
Propionic acid & 15.34 & 13.12 & 13.65 & 0.671 & 0.18 \\
Butyric acid & 15.06 & 9.80 & 9.70 & 1.772 & 0.075 \\
Isobutyric acid & 2.37 & 3.74 & 2.12 & 0.504 & 0.22 \\
Isovaleric acid & 2.88 & 3.53 & 2.25 & 0.370 & 0.25 \\
n-Valeric acid & 1.28 & 0.99 & 0.86 & 0.124 & 0.44 \\
n-Caproic acid & 0.11 & 0.13 & 0.22 & 0.034 & 0.56 \\
\hline
\end{tabular}

$\overline{\mathrm{a}, \mathrm{b}}$ Means within a row with different superscripts differ $(P<0.05)$.

${ }^{1} \mathrm{CRG}=$ corn grain diet; $\mathrm{CTP}=$ citrus pulp diet; $\mathrm{SYH}=$ soy hulls diet.

a safe and natural antimethanogenic additive. Bava et al. (2001) did not observe significant differences, but the value of energy losses as $\mathrm{CH}_{4}$ were 131 and $115 \mathrm{~kJ} /$ $\mathrm{kg}$ of $\mathrm{BW}^{0.75}$ for Saanen goats at midlactation fed a silage-based forage diet versus a nonforage diet. López and Fernández (2013) found no significant differences with midlactation Murciano-Granadina goats, obtaining an average value of $99 \mathrm{~kJ}$ of $\mathrm{CH}_{4} / \mathrm{kg}$ of $\mathrm{BW}^{0.75}$ when fed 2 mixed diets that differed in carbohydrate source (corn grain or by-products) and starch level.

The MEI was $(P<0.05)$ greater for diet CRG than SYH (1,193 vs. $1,079 \mathrm{~kJ} / \mathrm{kg}$ of $\mathrm{BW}^{0.75}$, respectively), whereas CTP showed an intermediate value $(1,147 \mathrm{~kJ} /$ $\mathrm{kg}$ of $\left.\mathrm{BW}^{0.75}\right)$. The HP was higher $(P<0.05)$ for the more fibrous diet than the more starchy diet (908 vs. $843 \mathrm{~kJ} / \mathrm{kg}$ of $\mathrm{BW}^{0.75}$ for $\mathrm{SYH}$ and $\mathrm{CRG}$, respectively). Lachica et al. (1997) found that the act of eating accounts for an energy cost of about 0.05 of the MEI for long-dried forage in goats, with similar values between species, so the cost of eating is higher in fibrous diets.
The $\mathrm{E}_{\text {milk }}$ presented no statistically significant differences among diets (400 kJ/kg of $\mathrm{BW}^{0.75}$, on average). The energy balance was negative for all treatments, indicating a mobilization of energy from reserves. Nevertheless, the higher starch content of the CRG diet decreased $(P<0.01)$ energy losses of tissues $(-23.4$ $\mathrm{kJ} / \mathrm{kg}$ of $\mathrm{BW}^{0.75}$ ) compared with $\mathrm{CTP}$ and SYH diet $\left(-184.8 \mathrm{~kJ} / \mathrm{kg}\right.$ of $\mathrm{BW}^{0.75}$, on average). The main reason this negative energy balance was found in our study is due to the quality of the forage and the level of feeding. The forage-to-concentrate ratio in our study was 14:86, with a low amount of forage (cereal straw) and of poor quality. Moreover, assuming an $\mathrm{ME}_{\mathrm{m}}$ of 401 $\mathrm{kJ} / \mathrm{kg}$ of $\mathrm{BW}^{0.75}$ (Aguilera et al., 1990), the value of level of feeding in our trial was 3.0, 2.9, and 2.7 for CRG, CTP, and SYH, respectively, lower than the recommendation for highly productive ruminants (ranging from 2 to more than 4 times maintenance, according to NRC, 2001). With our high-concentrate diets we expected greater DMI and, therefore, larger amounts of

Table 4. Daily energy partitioning $\left(\mathrm{kJ} / \mathrm{kg}\right.$ of $\left.\mathrm{BW}^{0.75}\right)$ of Murciano-Granadina goats $(\mathrm{n}=12)$ during midlactation according to the type of diet

\begin{tabular}{|c|c|c|c|c|c|c|c|c|c|}
\hline \multirow[b]{2}{*}{ Item $^{1}$} & \multicolumn{3}{|c|}{ Diet $^{2}$} & \multicolumn{2}{|c|}{ Period $^{3}$} & \multirow[b]{2}{*}{ SEM } & \multicolumn{3}{|c|}{$P$-value } \\
\hline & CRG & CTP & SYH & $\mathrm{A}$ & B & & Diet & Period & Diet $\times$ period \\
\hline GEI & $1,659.9$ & $1,628.6$ & $1,657.4$ & $1,629.3$ & $1,667.9$ & 23.56 & 0.87 & 0.49 & 0.24 \\
\hline $\mathrm{E}_{\mathrm{feces}}$ & $357.3^{\mathrm{b}}$ & $336.0^{\mathrm{b}}$ & $438.7^{\mathrm{a}}$ & 386.0 & 368.7 & 13.28 & 0.019 & 0.50 & 0.66 \\
\hline $\mathrm{E}_{\text {urine }}$ & 25.7 & 27.6 & 22.5 & 32.7 & 17.8 & 3.57 & 0.89 & 0.083 & 0.30 \\
\hline $\mathrm{E}_{\text {methane }}$ & $84.0^{\mathrm{b}}$ & $118.1^{\mathrm{a}}$ & $117.5^{\mathrm{a}}$ & 103.2 & 109.9 & 4.51 & 0.0001 & 0.20 & 0.096 \\
\hline MEI & $1,192.9^{\mathrm{a}}$ & $1,146.8^{\mathrm{ab}}$ & $1,078.7^{\mathrm{b}}$ & $1,107.5$ & $1,171.5$ & 21.80 & 0.033 & 0.063 & 0.018 \\
\hline $\mathrm{HP}$ & $842.7^{\mathrm{b}}$ & $862.5^{\mathrm{ab}}$ & $907.8^{\mathrm{a}}$ & 845.1 & 896.9 & 11.62 & 0.041 & 0.016 & 0.032 \\
\hline $\mathrm{E}_{\text {milk }}$ & 373.6 & 445.0 & 379.9 & 435.2 & 363.8 & 21.45 & 0.28 & 0.092 & 0.39 \\
\hline $\mathrm{RE}_{\text {body }}$ & $-23.4^{\mathrm{a}}$ & $-160.7^{\mathrm{b}}$ & $-208.9^{\mathrm{b}}$ & -172.9 & -89.2 & 30.71 & 0.0056 & 0.070 & 0.045 \\
\hline
\end{tabular}

$\overline{\mathrm{a}, \mathrm{b}}$ Means within a row with different superscripts differ $(P<0.05)$.

${ }^{1} \mathrm{GEI}=$ gross energy intake; $\mathrm{E}_{\mathrm{feces}}=$ energy losses in feces; $\mathrm{E}_{\text {urine }}=$ energy losses in urine; $\mathrm{E}_{\text {methane }}=$ energy losses in methane; $\mathrm{MEI}=$ metabolizable energy intake; $\mathrm{HP}=$ heat production; $\mathrm{E}_{\text {milk }}=$ recovered energy in milk; $\mathrm{RE}_{\mathrm{body}}=$ recovered energy in tissue $\left(\mathrm{RE} \mathrm{body}_{\mathrm{b}}=\mathrm{MEI}-\mathrm{HP}-\mathrm{E}_{\text {milk }}\right)$. ${ }^{2} \mathrm{CRG}=$ corn grain diet; $\mathrm{CTP}=$ citrus pulp diet; $\mathrm{SYH}=$ soy hulls diet.

${ }^{3} \mathrm{~A}=$ first period; $\mathrm{B}=$ second period. 
MEI, but it was not possible to reach higher DMI with the by-product diets. In ruminants, lipogenic nutrients originate either from fiber that stimulates the ruminal production of acetate and butyrate or from dietary fat, or are derived from body reserves. Glucogenic nutrients originate from starch escaped from rumen degradation or gluconeogenesis and include propionic acid, glucogenic amino acids, and lactic acid (van Knegsel et al., 2007). Lipogenic nutrients, which increase milk fat yield, increase the partitioning of ME into milk and consequently decrease the partitioning of ME into body reserves. These observations suggest that glucogenic nutrients (as in the CRG diet) stimulate body fat deposition and the partitioning of ME into body tissue so that less negative energy balance was observed. As mentioned previously, despite of the differences among diets in negative energy retention, no significant differences were found in $\mathrm{E}_{\text {milk }}$.

The efficiency of use of ME for milk production obtained by regression was 0.59 (corrected $\mathrm{E}_{\text {milk }}=-368.56$ $+0.591 \times$ corrected MEI; $\mathrm{R}^{2}=0.86$; residual standard deviation $=60.2]$. Different authors obtained greater values, such as Aguilera et al. (1990) with lactating Granadina goats $\left(\mathrm{k}_{\mathrm{l}}=0.67\right)$ or Bava et al. (2001), who found values ranging from 0.60 to 0.73 for Saanen goats during lactation. Moreover, Tovar-Luna et al. (2010), with Alpine goats during lactation, found values ranging from 0.66 to 0.78 . Those authors found variability when combining different stages of lactation with feed intake level, one of the reasons for differences in efficiencies being related to the complexity of biochemical transformation in tissues that are being synthesized or mobilized. López and Fernández (2013), with mixed diets and goats at midlactation and positive energy balance, found values around 0.63 . Therefore, when we estimate the $\mathrm{ME}_{\mathrm{m}}$, we found values higher $(624 \mathrm{~kJ} / \mathrm{kg}$ of $\mathrm{BW}^{0.75}$ ) than previous authors; Aguilera et al. (1990) found values of $401 \mathrm{~kJ} / \mathrm{kg}$ of $\mathrm{BW}^{0.75}$ for Granadina goats and Tovar-Luna et al. (2010) found $\mathrm{ME}_{\mathrm{m}}$ values of $431 \mathrm{~kJ} / \mathrm{kg}$ of $\mathrm{BW}^{0.75}$, on average. In our study, most of the lactating goats were in negative energy balance and some of the reasons for the dissimilar findings for level of body fat reserves in goats were related to basal metabolism to support milk secretion. Moreover, when a linear model is used to regress energy recovered and MEI, the intercept of the relationship and the $\mathrm{ME}_{\mathrm{m}}$ are determined using data obtained with animals receiving different MEI and they are then considered to be constant, irrespective of the ME supply to the animal. Therefore, the traditional assumption of a constant $\mathrm{ME}_{\mathrm{m}}$ that is independent of the MEI may be wrong. In the review of Kebreab et al. (2003), using nonlinear regression approach with 652 lactating dairy cows, the calculated values of $\mathrm{ME}_{\mathrm{m}}$ were higher (between 590 and
$620 \mathrm{~kJ} / \mathrm{kg}$ of $\mathrm{BW}^{0.75}$, with average $\mathrm{k}_{1}$ values of 0.55 ) than AFRC (1993) and NRC (2001) recommendations (490 and $510 \mathrm{~kJ} / \mathrm{kg}$ of $\mathrm{BW}^{0.75}$ for $\mathrm{ME}_{\mathrm{m}}$ and $\mathrm{k}_{\mathrm{l}}$ values of 0.62 and 0.64 , respectively).

Net energy for lactation was expressed as megajoules per kilogram of DM and no significant differences were found when substituting corn with fibrous by-products, although a lower value was found in soybean hulls diet (7.7 in CRG, 7.3 in CTP, and 6.6 in SYH). Diets were isoenergetic, and most of the variation observed in $\mathrm{NE}_{\mathrm{L}}$ was due to changes from starch to fiber (NDF). Bava et al. (2001), with goats at midlactation, found values of 8.5 and $7.7 \mathrm{MJ} / \mathrm{kg}$ of DM for silage-based and nonforage diets, respectively. The average value obtained by López and Fernández (2013) in dairy goats at midlactation was $7.5 \mathrm{MJ} / \mathrm{kg}$ of $\mathrm{DM}$ when corn grain was replaced by a blend of soybean hulls and corn gluten feed.

\section{Oxidation of Nutrients}

The $\mathrm{CO}_{2}$ production is derived from nutrient oxidation and rumen fermentation. The separation between these 2 components is necessary to calculate the substrate oxidation in ruminants and determine the proportion of substrate oxidation supporting the total HP associated with oxidative processes. The proportional contribution to HPx due to oxidation of nutrients is shown in Table 5 . The significant $(P<0.05)$ effect of period was related to the stage of lactation. Although both periods were midlactation, first period was closer to the peak of lactation than the second period. Thus, higher oxidation of fat and lower RQnpx were found during the first period, and greater oxidation of carbohydrates and RQnpx were observed during the second period. Effect of interaction was significant $(P<0.05)$ for fat and carbohydrate oxidation and RQnpx, and this interaction was not studied.

Diet had no significant effect on HPx $(853 \mathrm{~kJ} / \mathrm{kg}$ of $\mathrm{BW}^{0.75}$, on average). However, more fibrous diets (CTP and $\mathrm{SYH})$ were accompanied by greater $(P<0.001)$ HPf than the starch diet (CRG). A significant difference $(P<0.05)$ was observed for RQnpx, being significantly lower for SYH (0.77) than CTP (0.81), and CRG (0.79) did not differ from the other 2 diets but in all cases was lower than 1. Chwalibog et al. (1997) reported that RQnpx lower than 1 indicates predominance of OXF versus OXCHO, as we found in our study.

Due to the negative energy balance of goats, OXF was higher than OXCHO in all diets. The heat from OXP contributed about $8 \%$ of HPx on average for the 3 treatments. The CTP diet oxidized $58.2 \%$ of nutrients as OXF, but only $34.3 \%$ as OXCHO. However, the nutrient oxidation of OXF increased significantly 
Table 5. Heat production $\left(\mathrm{kJ} / \mathrm{kg}\right.$ of $\left.\mathrm{BW}^{0.75}\right)$ from oxidation and fermentation; daily oxidation $\left(\mathrm{kJ} / \mathrm{kg}\right.$ of $\left.\mathrm{BW}^{0.75}\right)$ of protein, carbohydrate, and fat; and their contribution to the heat production from oxidation substrates (\%) of Murciano-Granadina goats ( $\mathrm{n}=12)$ during midlactation according to the type of diet

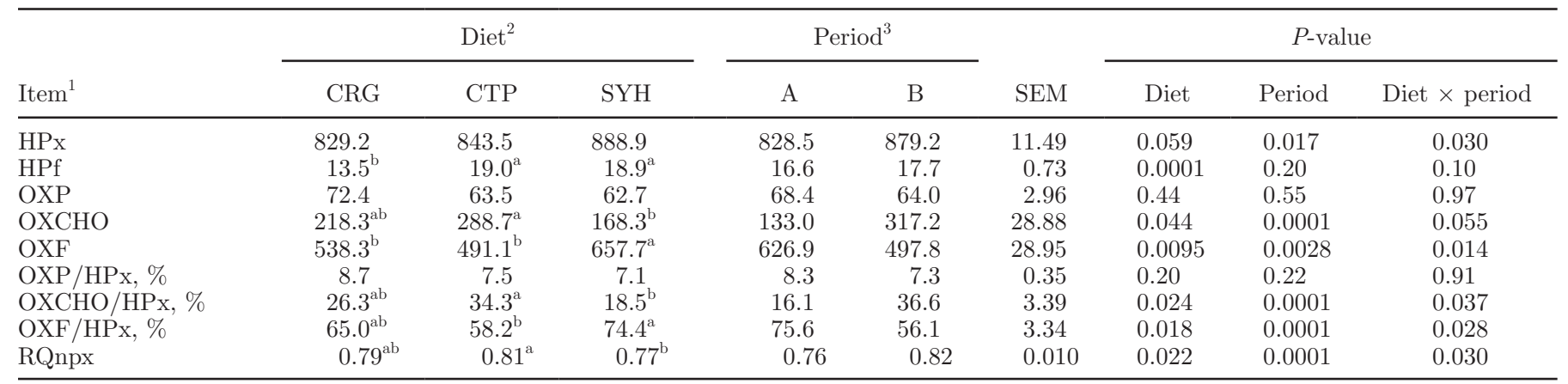

\footnotetext{
${ }^{\mathrm{a}, \mathrm{b}}$ Means within a row with different superscripts differ $(P<0.05)$.

${ }^{1} \mathrm{HPx}=$ heat production from oxidation of nutrients; HPf $=$ heat production of fermentation $[\mathrm{HPf}=\mathrm{HP}-\mathrm{HPx}(\mathrm{Brouwer}, 1958)]$; OXP $=$ heat production associated with the oxidation of protein; $\mathrm{OXCHO}=$ heat production associated with the oxidation of carbohydrates; OXF $=$ heat production associated with the oxidation of fat; $\mathrm{RQnpx}=$ nonprotein respiratory quotient (unitless) from oxidation of nutrients $\left\{\left[\mathrm{CO}_{2 \mathrm{x}}-\left(\mathrm{N}_{\text {urine }}\right.\right.\right.$ $\times 6.25 \times 0.774)] /\left[\mathrm{O}_{2}-\left(\mathrm{N}_{\text {urine }} \times 6.25 \times 0.957\right)\right]$, where $\mathrm{CO}_{2}=\mathrm{CO}_{2}$ production from oxidation and $\mathrm{N}_{\text {urine }}=\mathrm{N}$ in urine $\}$.

${ }^{2} \mathrm{CRG}=$ corn grain diet; $\mathrm{CTP}=$ citrus pulp diet; $\mathrm{SYH}=$ soy hulls diet.

${ }^{3} \mathrm{~A}=$ first period; $\mathrm{B}=$ second period.
}

$(P<0.05)$ to $74.4 \%$ in $\mathrm{SYH}$ and nutrient oxidation of OXCHO decreased significantly $(P<0.05)$ to $18.5 \%$. The higher amount of NDSF in the CTP diet promotes the higher OXCHO compared with the SYH diet. Nevertheless, the CRG diet presented intermediate values compared with the other 2 diets. Few studies relating to oxidation of nutrients are available for ruminants, and especially for small ruminants. López and Fernández (2013) found higher oxidation of nutrients in OXCHO than OXF in goats in midlactation because the goats in their experiment were in a positive energy balance. Chwalibog et al. (1997), in calves with positive retained energy as fat, reported that part of OXF should originate from ingested carbohydrate, mainly fiber.

\section{Carbon and Nitrogen Balance}

The daily $\mathrm{C}$ and $\mathrm{N}$ balance and the calculated tissue recovered as protein and fat are displayed in Table 6 . No effect of interaction between diet and period was observed. Effect of period was significant $(P<0.05)$ in carbon losses in $\mathrm{CO}_{2}$, recovered $\mathrm{N}$ in tissue, and $\mathrm{R}_{\text {protein }}$, following the same tendency as observed during the energy balance. In relation to diet, no significant differences were observed in $\mathrm{C}$ intake among treatments $\left(38.6 \mathrm{~g} / \mathrm{kg}\right.$ of $\mathrm{BW}^{0.75}$, on average), but $\mathrm{C}$ losses in feces were $2.2 \mathrm{~g} / \mathrm{kg}$ of $\mathrm{BW}^{0.75}$ greater in SYH than $\mathrm{CRG}$ and CTP due to the lower digestibility of DM of this diet. Carbon in urine tended $(P=0.056)$ to be higher with the CTP diet due to higher digestibility of DM and OM together with soluble fiber fractions (NDSF and NFC).

Following the trend observed for methane energy, the $\mathrm{C}$ losses in $\mathrm{CH}_{4}$ were significantly lower with $\mathrm{CRG}$ due to lower $\mathrm{CH}_{4}$ production with this diet. Carbon losses in $\mathrm{CO}_{2}$ show the same differences among diets as $\mathrm{C}$ in $\mathrm{CH}_{4}$. Carbon secreted into the milk was not significantly affected by treatment. The ratios between milk $\mathrm{C}$ output and $\mathrm{C}$ ingested were $0.21,0.24$, and 0.20 for CRG, CTP, and SYH, respectively. The CTP diet showed greater efficiency, with more $\mathrm{C}$ retained in milk in terms of intake. The 3 groups had negative balances, although CRG diet had significantly less negative balance $\left(-0.42 \mathrm{~g} / \mathrm{kg}\right.$ of $\left.\mathrm{BW}^{0.75} ; P<0.05\right)$ in comparison with the SYH diet $\left(-3.94 \mathrm{~g} / \mathrm{kg}\right.$ of $\mathrm{BW}^{0.75}$, on average).

Goats of the 3 groups ingested similar amounts of $\mathrm{N}\left(2.36 \mathrm{~g} / \mathrm{kg}\right.$ of $\mathrm{BW}^{0.75}$, on average). The $\mathrm{N}$ losses in feces were greater for the SYH treatment $(0.81 \mathrm{~g} / \mathrm{kg}$ of $\left.\mathrm{BW}^{0.75}\right)$ when compared with CRG and CTP $(0.66 \mathrm{~g} / \mathrm{kg}$ of $\mathrm{BW}^{0.75}$, on average). Nitrogen losses in urine and $\mathrm{N}$ secreted into the milk were not affected by treatment. Therefore, the ratios between milk $\mathrm{N}$ output and $\mathrm{N}$ ingested were similar among groups and presented an average value of 0.27 . The $\mathrm{N}$ balance was different $(P<$ 0.05) between CRG and SYH, although CTP was not different from the others. The $\mathrm{N}$ balance was positive for all treatments. Although some authors (Kebreab et al., 2010) indicated a reduction in urinary $\mathrm{N}$ output when MEI increased; in our study, greater and nonsignificant values of urinary $\mathrm{N}$ were found for the CRG diet (diet with higher MEI). This was probably due to greater $\mathrm{NH}_{3}-\mathrm{N}$ found in $\mathrm{CRG}$ and, consequently, more urea $\mathrm{N}$ excreted in urine. Therefore, this numerically higher urinary $\mathrm{N}$ excretion in diet based on corn would indicate an inefficient use of ruminal $\mathrm{NH}_{3}-\mathrm{N}$ for ruminal proteosynthesis, even when rapidly degraded starch was available for ruminal microorganisms. 
Table 6. Carbon and nitrogen balance $\left(\mathrm{g} / \mathrm{kg}\right.$ of $\left.\mathrm{BW}^{0.75}\right)$ of Murciano-Granadina goats $(\mathrm{n}=12)$ during midlactation according to the type of diet

\begin{tabular}{|c|c|c|c|c|c|c|c|c|c|}
\hline Item $^{1}$ & \multicolumn{3}{|c|}{$\operatorname{Diet}^{2}$} & \multicolumn{2}{|c|}{ Period $^{3}$} & SEM & \multicolumn{3}{|c|}{$P$-value } \\
\hline $\mathrm{C}_{\text {intake }}$ & 37.87 & 39.36 & 38.62 & 38.19 & 39.04 & 0.548 & 0.58 & 0.50 & 0.24 \\
\hline $\mathrm{C}_{\text {urine }}$ & 1.02 & 1.39 & 1.12 & 1.16 & 1.19 & 0.058 & 0.056 & 0.80 & 0.84 \\
\hline $\mathrm{C}_{\mathrm{CO} 2}$ & $19.47^{\mathrm{b}}$ & $20.92^{\mathrm{a}}$ & $21.06^{\mathrm{a}}$ & 19.37 & 21.59 & 0.348 & 0.019 & 0.0004 & 0.093 \\
\hline $\mathrm{C}_{\mathrm{CH} 4}$ & $1.52^{\mathrm{b}}$ & $2.13^{\mathrm{a}}$ & $2.12^{\mathrm{a}}$ & 1.86 & 1.99 & 0.082 & 0.0001 & 0.20 & 0.096 \\
\hline $\mathrm{N}_{\text {intake }}$ & 2.46 & 2.35 & 2.28 & 2.33 & 2.39 & 0.039 & 0.184 & 0.48 & 0.23 \\
\hline $\mathrm{N}_{\text {feces }}$ & $0.63^{\mathrm{b}}$ & $0.69^{\mathrm{b}}$ & $0.81^{\mathrm{a}}$ & 0.73 & 0.69 & 0.021 & 0.0018 & 0.22 & 0.74 \\
\hline $\mathrm{N}_{\text {urine }}$ & 0.63 & 0.55 & 0.54 & 0.59 & 0.56 & 0.026 & 0.44 & 0.55 & 0.97 \\
\hline Metabolizable N & 1.20 & 1.10 & 0.93 & 1.01 & 1.15 & 0.050 & 0.061 & 0.13 & 0.32 \\
\hline $\mathrm{N}_{\text {milk }}$ & 0.64 & 0.66 & 0.63 & 0.68 & 0.61 & 0.027 & 0.87 & 0.20 & 0.77 \\
\hline $\mathrm{N}$ retained body & $0.56^{\mathrm{a}}$ & $0.44^{\mathrm{ab}}$ & $0.30^{\mathrm{b}}$ & 0.33 & 0.54 & 0.046 & 0.034 & 0.0098 & 0.43 \\
\hline $\mathrm{R}_{\text {protein }}$ & $3.50^{\mathrm{a}}$ & $2.74^{\mathrm{ab}}$ & $1.89^{\mathrm{b}}$ & 2.03 & 3.39 & 0.287 & 0.034 & 0.0098 & 0.43 \\
\hline
\end{tabular}

${ }^{\mathrm{a}, \mathrm{b}}$ Means within a row with different superscripts differ $(P<0.05)$.

${ }^{1} \mathrm{C}_{\text {intake }}=\mathrm{C}$ intake; $\mathrm{C}_{\text {feces }}=\mathrm{C}$ losses in feces; $\mathrm{C}_{\text {urine }}=\mathrm{C}$ losses in urine; $\mathrm{C}_{\mathrm{CO} 2}=\mathrm{C}$ losses in $\mathrm{CO}_{2} ; \mathrm{C}_{\mathrm{CH} 4}=\mathrm{C}$ losses in methane; $\mathrm{C}_{\text {milk }}=$ recovered $\mathrm{C}$ in milk; $\mathrm{C}$ retained body $=$ recovered $\mathrm{C}$ in tissue; $\mathrm{N}_{\text {intake }}=\mathrm{N}$ intake; $\mathrm{N}_{\text {feces }}=\mathrm{N}$ losses in feces; $\mathrm{N}_{\text {urine }}=\mathrm{N}$ losses in urine; Metabolizable $\mathrm{N}=$ $\mathrm{N}_{\text {intake }}-\mathrm{N}_{\text {feces }}-\mathrm{N}_{\text {urine }} ; \mathrm{N}_{\text {milk }}=$ recovered $\mathrm{N}$ in milk; $\mathrm{N}$ retained body $=$ recovered $\mathrm{N}$ in tissue; $\mathrm{R}_{\text {protein }}=$ retained protein; $\mathrm{R}_{\text {fat }}=$ retained fat. ${ }^{2} \mathrm{CRG}=$ corn grain diet; $\mathrm{CTP}=$ citrus pulp diet; $\mathrm{SYH}=$ soy hulls diet.

${ }^{3} \mathrm{~A}=$ first period; $\mathrm{B}=$ second period.

The values of $\mathrm{N}$ retained in the body were converted to grams of protein. Differences $(P<0.05)$ were found between CRG and SYH, whereas CTP showed a middle value. Therefore, $\mathrm{R}_{\text {protein }}$ was $3.5,2.7$, and $1.9 \mathrm{~g} / \mathrm{kg}$ of $\mathrm{BW}^{0.75}$ for CRG, CTP, and SYH, respectively. Regarding $\mathrm{R}_{\text {fat }}$, the CTP and SYH diets showed greater $(P<$ $0.05)$ fat mobilization $\left(-6.0 \mathrm{~g} / \mathrm{kg}\right.$ of $\mathrm{BW}^{0.75}$, on average) than CRG $\left(-2.9 \mathrm{~g} / \mathrm{kg}\right.$ of $\left.\mathrm{BW}^{0.75}\right)$.

\section{Milk Production}

Table 7 reports the main productive results of the goats in the experiment. No effect of period was found for milk yield and composition. However, an effect of interaction was observed for DM, fat, and protein of milk. Diet had no effect on milk yield; average milk yield was $1.72 \mathrm{~kg} / \mathrm{d}$. However, a numerically higher milk yield was found for CTP than CRG and for CRG than SYH. Increased milk fat content is common when dietary fiber concentrations increase at the expense of starch. Significant differences $(P<0.01)$ were observed for milk fat between SYH and CRG (6.57 and 4.95\%, respectively) and, consequently, milk DM was also higher (16.06 and $14.02 \%$ for SYH and CRG, respectively). This was because the SYH diet had greater fiber content (Table 1), greater NDF and ADF digestibility (Table 2), and higher values of acetic acid in rumen fluid than CRG (Table 3). The depression in milk fat with CRG diet can be explained by a shift from a high availability of fat precursors to glucose and by a shift from lipogenesis to gluconeogenesis (van
Knegsel et al., 2007). Moreover, milk fat content was higher for goats fed a fibrous diet and with greater fat mobilization (Table 6). Milk protein content differed between SYH and CTP (4.16 and 3.44\%, respectively). Lactose content was not statistically different among treatments $(4.55 \%$, on average).

\section{Methane Emissions}

The effect of diet and period on $\mathrm{CH}_{4}$ emissions are shown in Table 8. No effect of period and its interaction with diet was found. Goats fed CTP and SYH diets produced similar $\mathrm{CH}_{4}$ emissions $(34.8 \mathrm{~g} / \mathrm{d}$, on average) and were significantly higher $(P<0.05)$ compared with goats fed CRG diet $(24.7 \mathrm{~g} / \mathrm{d})$. The type of carbohydrates in the diet influenced the proportion of individual VFA formed in the rumen and, thus, the amount of $\mathrm{CH}_{4}$ produced. According to Johnson and Johnson (1995), fermentation of fibrous carbohydrates produces more $\mathrm{CH}_{4}$ than fermentation of soluble sugars, which in turn produce more $\mathrm{CH}_{4}$ than fermentation of starch. The similar $\mathrm{CH}_{4}$ production that we found between CTP and SYH can be explained by the fact that CTP, although with a lower NDF content, has considerable amount of pectins, which, similar to hemicellulose and cellulose, are fermented to VFA and primarily to acetic acid, which promotes methanogenesis.

Methane emission as a percent of MEI and in grams per kilogram of DMI was greater $(P<0.001)$ for the CTP and SYH diets (10.6\% and $22.4 \mathrm{~g} / \mathrm{kg}$, on average) than the CRG diet $(7.0 \%$ and $16.4 \mathrm{~g} / \mathrm{kg})$. Methane con- 
Table 7. Daily milk production and composition of Murciano-Granadina goats $(\mathrm{n}=12)$ during midlactation according to the type of diet

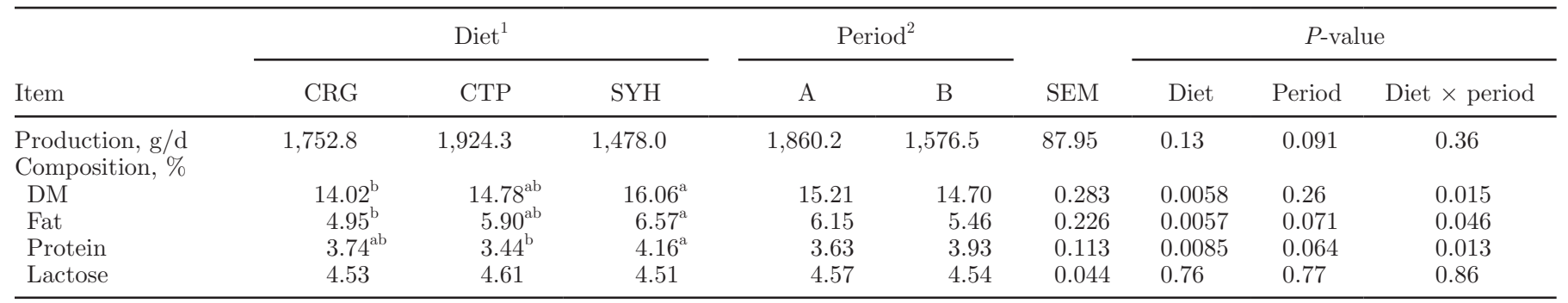

$\overline{\mathrm{a}, \mathrm{b}}$ Means within a row with different superscripts differ $(P<0.05)$.

${ }^{1} \mathrm{CRG}=$ corn grain diet; $\mathrm{CTP}=$ citrus pulp diet; $\mathrm{SYH}=$ soy hulls diet.

${ }^{2} \mathrm{~A}=$ first period; $\mathrm{B}=$ second period.

version ratio, also called Ym factor, represents energy loss as $\mathrm{CH}_{4}$ per unit of GE intake. Methane conversion ratio for CTP and SYH was $7.2 \%$, on average, and CRG showed a value of $5.1 \%(P<0.001)$. Kreuzer et al. (1986) also found significantly lower $\mathrm{CH}_{4}$ loss (total as well as percent of GE) on rations with native starch than rations with cellulose. Although $\mathrm{CH}_{4}$ emission is most commonly expressed in the literature relative to GE intake, the most meaningful expression is relative to intake of digestible OM because of its high correlation with ruminally fermented OM. On these bases, ruminal $\mathrm{CH}_{4}$ emission was also greater $(P<0.001)$ with $\mathrm{CTP}$ and SYH as compared with CRG. The $\mathrm{CH}_{4}$ production per kilogram of OM digested was $10.1 \mathrm{~g}$ higher in byproduct diets, on average, than CRG.

When we report the $\mathrm{CH}_{4}$ production related to the energy-to-protein ratio we found the same tendency. Thus, this ratio is MEI divided by metabolizable $\mathrm{N}$ $\left[\mathrm{MJ} / \mathrm{g}=\mathrm{MEI} /\left(\mathrm{N}_{\text {intake }}-\mathrm{N}_{\text {feces }}-\mathrm{N}_{\text {urine }}\right)\right]$ and the values obtained were $1.03,1.05$, and 1.17 for CRG, CTP and $\mathrm{SYH}$, respectively. This means more $\mathrm{CH}_{4}$ was produced when more MEI was available per unit of metabolizable N. Bava et al. (2001) found the same trend with lactating Saanen goats comparing a nonforage diet with a forage diet; as more $\mathrm{CH}_{4}$ was emitted, more energy and $\mathrm{N}$ ratio was observed (1.42 vs. $1.33 \mathrm{MJ} / \mathrm{g}$ of $\mathrm{N}$ for the forage and nonforage diet, respectively). As Dijkstra et al. (2013) indicated, integration between protein and energy metabolism is essential, and energy and protein should be considered together rather than as 2 distinct entities. When the relationship between $\mathrm{CH}_{4}$ production and milk production was compared we found that goats fed SYH produced $8.0 \mathrm{~g}$ of $\mathrm{CH}_{4} / \mathrm{kg}$ of milk more $(P<0.01)$ than goats fed CRG; conversely, the CTP diet presented intermediate values.

\section{CONCLUSIONS}

Our study provides data on energy partitioning, substrate oxidation, carbon and nitrogen balances, methane emissions, and milk performance in MurcianoGranadina goats during midlactation fed mixed diets. The replacement of $61 \%$ of corn in the diet by dry citrus pulp or soybean hulls did not affect milk yield (1.72 $\mathrm{kg} / \mathrm{d}$ ) and more fat content was observed for fibrous diets $(6.57,5.90$, and $4.95 \%$ in SYH, CTP, and CRG, respectively). The MEI was greater for diet CRG than SYH $\left(1,193\right.$ vs. $1,079 \mathrm{~kJ} / \mathrm{kg}$ of $\mathrm{BW}^{0.75}$, respectively),

Table 8. Methane emission of Murciano-Granadina goats $(\mathrm{n}=12)$ during midlactation according to the type of diet

\begin{tabular}{|c|c|c|c|c|c|c|c|c|c|}
\hline \multirow[b]{2}{*}{ Item $^{1}$} & \multicolumn{3}{|c|}{$\operatorname{Diet}^{2}$} & \multicolumn{2}{|c|}{ Period $^{3}$} & \multirow[b]{2}{*}{ SEM } & \multicolumn{3}{|c|}{$P$-value } \\
\hline & CRG & $\mathrm{CTP}$ & SYH & $\mathrm{A}$ & B & & Diet & Period & Diet $\times$ period \\
\hline $\mathrm{CH}_{4}, \mathrm{~g} / \mathrm{d}$ & $24.68^{\mathrm{b}}$ & $35.09^{\mathrm{a}}$ & $34.42^{\mathrm{a}}$ & 30.41 & 32.38 & 1.334 & 0.0001 & 0.23 & 0.39 \\
\hline $\mathrm{Ym}, \%$ & $5.06^{\mathrm{b}}$ & $7.28^{\mathrm{a}}$ & $7.09^{\mathrm{a}}$ & 6.34 & 6.61 & 0.282 & 0.0001 & 0.41 & 0.50 \\
\hline $\mathrm{CH}_{4} / \mathrm{MEI}, \%$ & $7.02^{\mathrm{b}}$ & $10.33^{\mathrm{a}}$ & $10.90^{\mathrm{a}}$ & 9.36 & 9.48 & 0.462 & 0.0001 & 0.79 & 0.52 \\
\hline $\mathrm{CH}_{4}, \mathrm{~g} / \mathrm{kg}$ of DMI & $16.37^{\mathrm{b}}$ & $22.96^{\mathrm{a}}$ & $21.92^{\mathrm{a}}$ & 19.97 & 20.86 & 0.836 & 0.0001 & 0.41 & 0.49 \\
\hline $\mathrm{CH}_{4}, \mathrm{~g} / \mathrm{kg}$ of $\mathrm{OM}$ digested & $22.00^{\mathrm{b}}$ & $30.93^{\mathrm{a}}$ & $33.20^{\mathrm{a}}$ & 28.42 & 29.01 & 1.298 & 0.0001 & 0.66 & 0.59 \\
\hline $\begin{array}{l}\text { MEI, MJ/g of metabolizable } \\
\mathrm{N}\end{array}$ & 1.03 & 1.05 & 1.17 & 1.12 & 1.04 & 0.035 & 0.23 & 0.25 & 0.83 \\
\hline $\mathrm{CH}_{4}, \mathrm{~g} / \mathrm{kg}$ of milk & $15.46^{\mathrm{b}}$ & $18.47^{\mathrm{ab}}$ & $23.46^{\mathrm{a}}$ & 17.26 & 21.00 & 1.174 & 0.0078 & 0.052 & 0.26 \\
\hline
\end{tabular}

$\overline{\mathrm{a}, \mathrm{b}}$ Means within a row with different superscripts differ $(P<0.05)$.

${ }^{1} \mathrm{Ym}=$ methane energy/gross energy intake; MEI = metabolizable energy intake.

${ }^{2} \mathrm{CRG}=$ corn grain diet; $\mathrm{CTP}=$ citrus pulp diet; $\mathrm{SYH}=$ soy hulls diet.

${ }^{3} \mathrm{~A}=$ first period; $\mathrm{B}=$ second period. 
and CTP showed an intermediate value $(1,147 \mathrm{~kJ} / \mathrm{kg}$ of $\left.\mathrm{BW}^{0.75}\right)$. The HP was higher for the more-fibrous diet than the more-starchy diet (908 vs. $843 \mathrm{~kJ} / \mathrm{kg}$ of $\mathrm{BW}^{0.75}$ for SYH and CRG, respectively). The efficiency of use of $\mathrm{ME}$ for milk production obtained by regression was 0.59. Replacement with fibrous by-products increased methane emissions. Greater $\mathrm{CH}_{4}$ was produced with dry citrus pulp and soybean hulls diets $(34.8 \mathrm{~g} / \mathrm{d}$ on average) than the corn diet $(24.7 \mathrm{~g} / \mathrm{d})$. The higher-starch diet resulted in more energy to be partitioned into the body, whereas the fibrous diet split more energy into milk fat. Hence, lactating goats could use dry citrus pulp and soybean hulls diets without detrimental effect on milk performance, although attention should be paid to the quality of forage and level of feeding.

\section{ACKNOWLEDGMENTS}

This study was supported by the Instituto INIA Project (Madrid, Spain; ref. RTA2011-00107-C02-02).

\section{REFERENCES}

Agricultural and Food Research Council (AFRC). 1993. Energy and Protein Requirements of Ruminants. CAB International, Wallingford, UK.

Aguilera, J. F., and C. Prieto. 1986. Description and function of an open-circuit respiration plant for pigs and small ruminants and the techniques used to measure energy metabolism. Arch. Tieremahr. 36:1009-1018.

Aguilera, J. F., C. Prieto, and J. Fonollá. 1990. Protein and energy metabolism of lactating Granadina goats. Br. J. Nutr. 63:165-175.

AOAC International. 2000. Official Methods of Analysis. 17th ed. AOAC International, Arlington, VA.

Ariza, P., A. Bach, M. D. Stern, and M. B. Hall. 2001. Effects of carbohydrates from citrus pulp and hominy feed on microbial fermentation in continuous culture. J. Anim. Sci. 79:2713-2718.

Batey, I. L. 1982. Starch analysis using thermostable alpha-amylases. Starch 34:125-128.

Bava, L., L. Rapetti, G. M. Crovetto, A. Tamburini, A. Sandrucci, G. Galassi, and G. Succi. 2001. Effect of a non-forage diet on milk production, energy and nitrogen metabolism in dairy goats throughout lactation. J. Dairy Sci. 84:2450-2459.

Brockway, J. M., A. W. Boyne, and J. G. Gordon. 1971. Simultaneous calibration of gas analyzers and meters. J. Appl. Physiol. 31:296-297.

Brouwer, E. 1958. On simple formulae for calculating the heat expenditure and the quantities of carbohydrate and fat metabolized in ruminants, from data on gaseous exchange and urine N. Pages 182-194 in Proc. 11th Sym. Energy Metab. EAAP. Publ. 8. Academic Press, London, UK.

Brouwer, E. 1965. Report of sub-committee on constants and factors. Pages 441-443 in Proc. 13th Symposium on Energy Metabolism. K. L. Blaxter, ed. EAAP. Publ. 11. Academic Press, London, UK.

Calsamiglia, S., A. Bach, C. de Blas, C. Fernández, and P. GarcíaRebollar. 2009. Nutritional requirements for dairy ruminants. Fundación Española para el Desarrollo de la Nutrición Animal (FEDNA), Madrid, Spain.

Chwalibog, A., A. H. Tauson, and G. Thorbek. 1997. Quantitative oxidation of nutrients in growing calves. Z. Ernahrungswiss. $36: 313-316$.

Dijkstra, J., O. Oenema, J.W. van Groenigen, J.W. Spek, A.M. van Vuuren, and A. Bannink. 2013. Diet effects on urine composition of cattle and N2O emissions. Animal 7(Suppl. s2):292-302.
European Union. 2003. Protection of animals used for experimental purposes. Council Directive 86/609/EEC of 24 November 1986 , amended 16.9.2003. European Council, Brussels, Belgium.

Fahey, G. C., and L. L. Berger. 1988. Carbohydrate nutrition of ruminants. Pages 269-297 in The Ruminant Animal. Digestive Nutrition and Physiology. D. C. Church, ed. Prentice-Hall, Englewood Cliffs, NJ.

Fundación Española para el Desarrollo de la Nutrición Animal (FEDNA). 2010. Tablas FEDNA de composición y valor nutritivo de alimentos para la fabricación de piensos compuestos. 3rd ed. FEDNA, Madrid, Spain.

Fernández, C., M. C. López, and M. Lachica. 2012. Description and function of a mobile open-circuit respirometry system to measure gas exchange in small ruminants. Anim. Feed Sci. Technol. $172: 242-246$.

Grainger, C., and K. A. Beauchemin. 2011. Can enteric methane emissions from ruminants be lowered without lowering their production? Anim. Feed Sci. Technol. 166-167:308-320.

Grasser, L. A., J. G. Fadel, I. Garnett, and E. J. Depeters. 1995. Quantity and economic importance of nine selected by-products used in California dairy rations. J. Dairy Sci. 78:962-971.

Hall, M. B., B. A. Lewis, P. J. Van Soest, and L. E. Chase. 1997. A simple method for estimation of neutral detergent-soluble fibre. J. Sci. Food Agric. 74:441-449.

Johnson, K. A., and D. E. Johnson. 1995. Methane emissions in cattle. J. Anim. Sci. 73:2483-2492.

Jouany, J. P. 1982. Volatile fatty acid and alcohol determination in digestive contents, silage juices, bacterial cultures and anaerobic fermentor contents. Sci. Aliments 2:131-144.

Kawas, J. R., J. Lopes, D. L. Danelon, and C. D. Lu. 1991. Influence of forage-to-concentrate ratios on intake, digestibility chewing and milk production of dairy goats. Small Rumin. Res. 4:11-18.

Kebreab, E., J. France, R. E. Agnew, T. Yan, M. S. Dhanoa, J. Dijkstra, D. E. Beever, and C. K. Reynolds. 2003. Alternatives to linear analysis of energy balance data from lactating dairy cows. J. Dairy Sci. 86:2904-2913.

Kebreab, E., A. B. Strathe, J. Dijkstra, J. A. N. Mills, C. K. Reynolds, L. A. Crompton, T. Yan, and J. France. 2010. Energy and protein interactions and their effects on nitrogen excretion in dairy cows. Pages 417-426 in 3rd EAAP Int. Symp. Energy Protein Metab. Nutr., Parma, Italy. Publ. No. 127. EAAP, Rome, Italy.

Kreuzer, M., M. Kirchgessner, and H. L. Müller. 1986. Effect of defaunation on the loss of energy in wethers fed different quantities of cellulose and normal or steamflaked maize starch. Anim. Feed Sci. Technol. 16:233-241.

Lachica, M., and J. F. Aguilera. 2003. Estimation of energy needs in the free-ranging goat with particular reference to the assessment of its energy expenditure by the ${ }^{13} \mathrm{C}$-bicarbonate method. Small Rumin. Res. 49:303-318.

Lachica, M., J. F. Aguilera, and C. Prieto. 1997. Energy expenditure related to the act of eating in Granadina goats given diets of different physical form. Br. J. Nutr. 77:417-426.

López, M. C., and C. Fernández. 2013. Energy partitioning and substrate oxidation by Murciano-Granadina goats during mid lactation fed soy hulls and corn gluten feed blend as a replacement for corn grain. J. Dairy Sci. 96:4542-4552.

Martínez-Vallespín, B., C. Navarrete, E. Martínez-Paredes, L. Ródenas, C. Cervera, and E. Blas. 2011. Determination of neutral detergent soluble fibre: Modifications of the original method. Pages 291-293 in Proc. 14th Conf. Anim. Prod., AIDA-ITEA, Zaragoza, Spain.

McLean, J. A., and G. Tobin. 1987. Animal and Human Calorimetry. Cambridge University Press, Cambridge, UK.

Mertens, D. R. 2002. Gravimetric determination of amylase-treated neutral detergent fibre in feeds with refluxing beakers or crucibles: Collaborative study. J. AOAC Int. 85:1217-1240.

NRC. 2001. Nutrient Requirements of Dairy Cattle. 7 th rev. ed. Natl. Acad. Press, Washington, DC.

Robertson, J. B., and P. J. Van Soest. 1981. The detergent system of analysis and its application to human foods. Pages 123-142 in 
The Analysis of Dietary Fiber in Foods. W. P. T. James and O. Theander, ed. Marcel Dekker, New York, NY.

Romero-Huelva, M., E. Ramos-Morales, and E. Molina-Alcaide. 2012. Nutrient utilization, ruminal fermentation, microbial abundances, and milk yield and composition in dairy goats fed diets including tomato and cucumber waste fruits. J. Dairy Sci. 95:6015-6026.

SAS. 2001. User's Guide. Ver. 8.02. SAS Institute Inc. Cary, NC.

Tovar-Luna, I., R. Puchala, T. Sahlu, H. C. Freetly, and A. L. Goetsch. 2010. Effects of stage of lactation and dietary concentrate level on energy utilization by Alpine dairy goats. J. Dairy Sci. 93:48184828 van Knegsel, A. T. M., H. Brand, J. Dijkstra, W. M. Straalen, M. J. W. Heetkamp, S. Tamminga, and B. Kemp. 2007. Dietary energy source in dairy cows in early lactation: Energy partitioning and milk composition. J. Dairy Sci. 90:1467-1476.

Vasta, V., A. Nudda, A. Cannas, M. Lanza, and A. Priolo. 2008. Alternative feed resources and their effects on the quality of meat and milk from small ruminants. Anim. Feed Sci. Technol. 147:223246. 